Available for free online at https://ojs.hh.se/

JISTB

Journal of Intelligence Studies in Business 1 (2011) 97-106

\title{
Competitive Intelligence and Knowledge Creation - Outward insights from an empirical survey
}

\author{
Mourad Oubrich
}

\author{
Allal Al Fassi Avenue, Madinat Al Irfane \\ Rabat-Institutes- Morocco
}

oubrich@inpt.ac.ma

\begin{abstract}
Received 20 August 2011; received in revised form 23 August 2011; accepted 31 December 2011
\end{abstract}

\begin{abstract}
The 21st century is characterized by many transformations which have had an impact on the growth of companies, such as aggressive competition, layoff plans, terrorist attacks and rising oil prices. It is of importance for a company to develop a protection against future impediments. This can be done by creating knowledge through a competitive intelligence process, which is the main focus of this article. With different theories about knowledge creation and competitive intelligence at hand, a qualitative empirical study was developed. The article presents how a company's strategic intent, mission and strategic objectives can act as a guide for the competitive intelligence process, in order to gain the information necessary to find opportunities and eliminate threats.
\end{abstract}

Keywords: Competitive Intelligence, Knowledge creation, Knowledge management 


\section{Introduction}

\subsection{Creating Competitiveness}

The list given in the abstract is not exhaustive of the events that disrupt the international economic order and affect the growth of countries and companies. If we are able to draw conclusions from observing the environment, perform relevant actions involved in discontinuities and give them a useful meaning, it should be be possible to anticipate events, at least in theory. In order to forecast future developments it is necessary to identify the process that shapes knowledge creation in a company. The question so far is how we can help companies look forward to the future to protect themselves against threats and exploit opportunities. This question forces us to look beyond the competitiveness of a company and ask how they can sustain themselves over time. A development of a competitive intelligence process that boosts knowledge creation and innovation is a straightforward manner to ensure competitiveness. This article focuses on the knowledge creation part. It shows how the creation of new knowledge can be done in a competitive intelligence process.

\subsection{Problem Definition}

This study pursues two main issues: 1) the determination of the different mechanisms able to create knowledge and 2) how these mechanisms can develop new knowledge. To that end, the article will shed light on the difference between information and knowledge, as pointed out above. This clarification allows us to understand in depth how a competitive intelligence process creates new knowledge.

\section{Materials}

\subsection{Research Context}

Beginning in the mid-1980s, Michael E. Porter formed the basis of strategic thinking in business. According to Porter (1990) competitive strategy is about being different. It means deliberately choosing a different set of activities to deliver a unique mix of value. Moreover, the essence of strategy is choosing to perform activities differently than rivals do (Porter, 1990). In the beginning of the 90s, his approach was criticized. The first critique was addressed by Hamel and Prahalad (1989). Hamel (1996) explained that strategy should be stretched, not fit; competition should shape industry futures rather than merely positions within existing industries and resources should be leveraged rather than allocated. Indeed, since then the research in competitive strategy has integrated the Hamel and Prahalad's (1989) approach such as
Barney (1991). In his article he argued that sustained competitive advantage derives from the resources and capabilities a firm controls; that is valuable, rare, imperfectly imitable, and not substitutable. However, the diffusion of the resource-based view in strategic management and related disciplines has been both dramatic and controversial and has involved considerable theoretical developments and empirical testing (Barney, Wright \& Ketchen, 2001).

The issue regarding how competitive intelligence drives knowledge creation is becoming a major concern for many organizations. Research that has been undertaken around knowledge creation and the competitive intelligence process is somewhat rare (du Toit, 2003). In this research, we are going to suggest a way to help organizations to set up an efficient competitive intelligence process that allow them to create new knowledge. To do so, it is necessary to understand both competitive intelligence and knowledge creation.

\subsection{Theoretical Objectives}

There tends to be confusion between the concepts competitive intelligence and knowledge management.

Definition 1. Knowledge management is the capturing, filing and categorization of the information.

Definition 2. Competitive intelligence is the focusing, analyzing and "actioning" of data (du Toit, 2003).

Without knowledge management it is not possible to create competitive intelligence, as competitive intelligence requires access to information. However, without competitive intelligence, knowledge management becomes a fruitless exercise of filing and categorizing information (Calof, 2001).

The authors give their definition of the competitive intelligence concept. They believe competitive intelligence has the following characteristics:

1. It is an art of collecting, processing and storing information to be made available to people at all levels of the firm to help shape its future and protect it against current competitive threats

2. It should be legal and respect codes of ethics

3. It involves a transfer of knowledge from the environment to the organization within established rules (Rouach and Santi, 2001).

In this way, the intelligence cycle consists of four, by now well-known, stages that are essential to the process of decision-making: planning, collecting, 
analyzing and disseminating value-added information. To exploit information needs to be upto-date with market changes. It demands the learning of methods and strategies that supports the use of information for decision-making. To be successful in this environment, the actors need to acquire new combinations of skills. In particular, they need to learn skills that allow them to find, manage and share information and knowledge (du Toit, 2003). According to Levet (2001), the transformation of information to knowledge implies the mobilization of capacities to interpret and to give sense by learning. Achard and Bernat (1998) points out that a manager has a role in enriching data throughout the information cycle to transform information into exploitable intelligence, which can be used by decision-makers. In doing so, the organizations need to create a shared space for individual and collective knowledge creation - both physically and mentally.

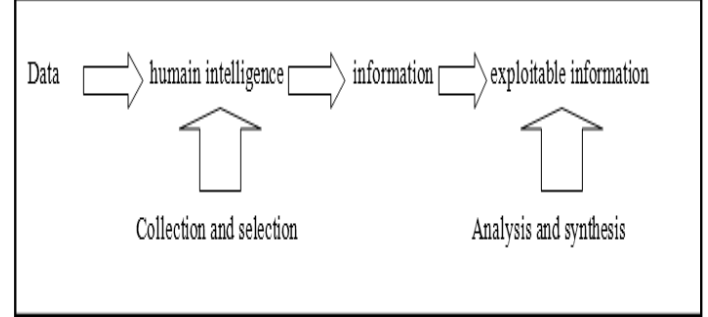

Figure 1: The information cycle

\subsection{Empirical Objectives}

In the absence of a conceptual framework for competitive intelligence, it is appropriate to use a qualitative research strategy. Our research adopted a qualitative methodology due to the need for rich data that can facilitate the generation of theoretical categories. Furthermore, a qualitative method is appropriate in new topic areas to develop a deeper understanding of the phenomenon and to aid theory development (Eisenhardt, 1989). In doing so, the study began by interviewing 20 directors engaged in competitive intelligence $(60 \%$ are competitive intelligence directors). The empirical study started in October 2003 and was wound up by March 2004.

\section{Theoretical Framework}

\subsection{Competitive Intelligence}

There are many definitions of competitive intelligence. The Society of Competitive Intelligence Professionals defines the term as:

The process of ethically collecting, analyzing and disseminating accurate, relevant, specific, timely, foresighted and actionable intelligence regarding the implications of the business environment, competitors and the organization itself.

According to Calof (2001), competitive intelligence is defined as:

An actionable recommendation arisen from a systematic process, involving planning, gathering, analyzing and disseminating information on the external environment, for opportunities or developments that have the potential to affect a company or a country's competitive situation.

Despite the positive impact and growth of competitive intelligence, there exists a variety of associated ethical issues that are still unresolved. First we notice that competitive intelligence is different from industrial espionage. For example, (Rittenburg et al. 2006) go further and propose a theoretical framework that outlines various factors that impact ethical decision-making in competitor intelligence gathering situations. They highlight that ethical decision-making for competitive intelligence gathering can be proactively managed. Crane (2005) point out that industrial espionage or spying is both unethical and illegal. There is sometimes a fine line between the legitimate tactics of competitive intelligence gathering and the illegitimate practice of industrial espionage. At the end competitive intelligence is conducted in order to gain more knowledge about things to come so that today's decisions can be based more solidly on available expertise than before. Prescott (1999) outlines a decision-oriented approach to design a competitive intelligence program.

\subsection{Knowledge Creation}

Knowledge creation is often like a moot question for any organization that operates in a competitive environment. Some researchers recognize the importance of knowledge for the competitive advantage of the firms. But, despite a great deal of discussion about knowledge creation, relatively little empirical evidence is available. To describe knowledge creation, this paragraph adopts the Nonaka and Takeuchi's (1994) model. This model outlines two fundamental elements of organizational knowledge creation theory: epistemology and knowledge conversion. Nonaka and Takeuchi (1994) highlight that one dimension of the knowledge creation process can be drawn from a distinction between two types of knowledge, identified by Polanyi (1966): tacit and explicit. 


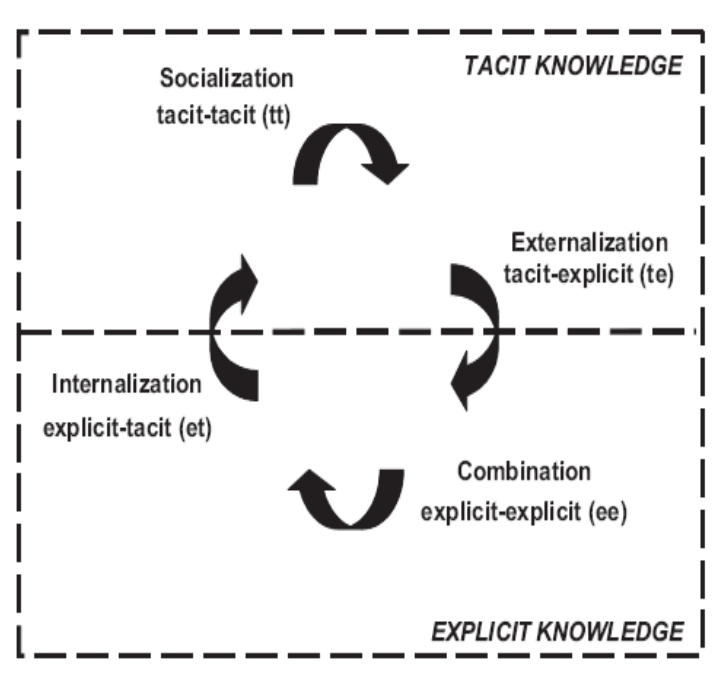

Figure 2: The SECI model

This process, put together with the four basic SECI epistemological processes, shapes the well-known knowledge-spiral of the company. Nonaka and Konno (1998) define the concept of " $B a$ " - a susceptible environment for knowledge creation in terms of networks, teams, and open organizational designs. Furthermore, Nonaka and Takeuchi (1995) describe the cognitive approach to knowledge creation as schemata - mental models and beliefs. It can be described as a perception which reflects our image of reality and our vision of the future. They consider this form of knowledge creation to be achieved through metaphors, pictures and experiences.

\subsection{Competitive Intelligence Process}

The competitive intelligence process is portrayed in Figure 1 as a continuous process, which is improved through feedback. Moreover, a distinction can be made between information and knowledge through this process. The notions of information and knowledge are often used in a different manner in the literature, including by those of authors who treat learning from an "informational perspective". The necessity to distinguish between information and knowledge is important for the pursuit of this research. If admitted that information contributes to the improvement of the knowledge, as claimed by the authors of the informational approach of the organizational learning, such as Argyris (1976); Argyris (1993); Cohen and Levinthal (1990); Huber (1991); Nonaka (1994), these two notions cannot be considered conceptually as equivalent. Knowledge drifts implies a certain transformation of information. According to Huber (1991), information designates a structured togetherness of data transporting a sense (or signal) whereas knowledge is a product generated by the treatment (interpretation) of information. For information that can be acquired, knowledge must be developed. For Argyris (1993), information constitutes an input necessary to the initiation and to the formalization of learning. The author defines information as being a flux of messages (or of signals) and knowledge like a belief verified concerning the human action that is founded on a flux of information. He uses this definition as formulated by Nonaka (1994); that all knowledge is founded on a basis, more or less complex, of information. A version of Nonaka and Takeuchi's (1995) definition of information will be used in this paper:

A structured togetherness of data providing some indications of the nature or the evolution of a fact, of a given phenomenon, and the notion of knowledge as being a true and justified belief.

Our research could not exclude reflections around this distinction between information and knowledge. Levet (2001) considers that the strategic dimension of competitive intelligence process resides in the triptych; appropriation (of information) - interpretation (of information) action. The appropriation is about the knowledge of an enterprise and the interpretation consists of clearing the sense of the strategy. Finally the action is founded on knowledge. Therefore the role of competitive intelligence is to create knowledge from information. Furthermore, competitive intelligence creates knowledge in terms of insights and understanding, known as tacit knowledge in users' heads. The outcome of competitive intelligence is decisions that improve and optimize business decisions (du Toit 2003).

\section{Theoretical results}

From a theoretical framework standpoint, organizational learning is a central mechanism in knowledge creation theory. The appropriate way to organize for effective knowledge creation would be to combine various types of organizational learning according to the strategic needs of an organization. Regarding organizational learning, the reflection was here based on Argyris and Schôn's (1978) work. The authors defined organizational learning as a process that implies the detection and the correction of an error. They distinguished two types of organizational learning (simple and double loop). The learning in simple loop is a compartmental process of adaptation and response or correction of error in the schema map or established organizational routines (learning by improvement of the basis of possessed knowledge). Whereas the learning in double loop is a cognitive process that, according

to 
Ingham (1994), implies a heuristic imaginative critique. It can be modifications in the diagrams of knowledge and answers or the production of new diagrams.

In light of the discussions and theory presented above, this process can then quite easily be represented (Argyris \& Schôn, 1978).

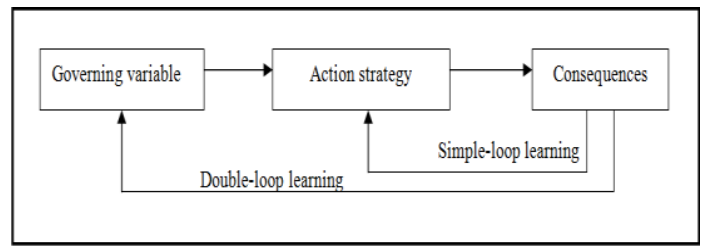

Figure 3: Theory of action

Recent discussion on organizational learning and knowledge creation has emphasized the role of sharing common strategic intent and collective representation in knowledge generation. These new concepts and their relationships with organizational learning is explained below:

1. Organizational learning as change in collective representations: Argyris and Schôn (1978) propose the basic foundation of the theory of action. From this theory we see how actors build their representation from information. To do that, the actors constantly refer to a collective framework or cognitive schema to act. In this sense, a competitive intelligence process can be seen as a place where the actors try to make up new representation regarding competitors, customers, and clients. The actors in this process interact in order to refine, to complete their representations; to test them and to evolve. In the same tentative explanation of organizational learning as knowledge creation mechanism, Cyert and March (1963) note that learning comes from a prompt or continual gap between a level of aspiration associated with an objective and the real level of performance.

2. Organizational learning as a result of a situational gap provoked by a strategic intent change: Charue (1992) specifies that there is organizational learning when the members of the organization construct actionable knowledge in relation to the organization's strategic intent. According to Campbell and Yeung (1991) and Lipton (1996), strategic intent is the answer to the question: why does the company exist?

\begin{tabular}{|c|l|l|l|}
\hline $\begin{array}{c}\text { Company } \\
\text { Number }\end{array}$ & & \multicolumn{1}{|c|}{ Position Title } & Interview Method \\
\hline 1 & & & Site \\
\hline 2 & Director, Competitive intelligence & Energy & Site \\
\hline 3 & Director, communication and marketing & Industrial Chemicals & Site \\
\hline 4 & Director, Human resource Management & Utility & Site \\
\hline 5 & Director, Competitive intelligence & Industrial Products & Site \\
\hline 6 & Director, Competitive intelligence & Energy & Site \\
\hline 7 & Director, Strategy & Utility & Site \\
\hline 8 & Director, Marketing & Services & Site \\
\hline 9 & Director, Competitive intelligence & Automotive & Site \\
\hline 10 & Director, Competitive intelligence & IT Services & Site \\
\hline 11 & Director, Competitive intelligence & Chemical Industry & Site \\
\hline 12 & Director, Knowledge management & IT Services & Site \\
\hline 13 & Director, Competitive intelligence & Services & Site \\
\hline 14 & Director, Competitive intelligence & Energy & Site \\
\hline 16 & Director, Knowledge management & Telecom & Site \\
\hline 17 & Director, Competitive intelligence & Energy & Site \\
\hline 18 & Director, Competitive intelligence & Semiconductor & Site \\
\hline
\end{tabular}

Table 1: Companies studied 


\begin{tabular}{|l|c|c|c|c|c|}
\hline & $\begin{array}{c}\Sigma \\
\text { Speech }\end{array}$ & $\begin{array}{c}\% \\
\text { Speech }\end{array}$ & $\begin{array}{c}\text { Number of Significant } \\
\text { word }\end{array}$ & $\begin{array}{c}\text { Number of word per } \\
\text { speech }\end{array}$ & \% Word/speech \\
\hline CI Director & 12 & 60 & 334 & 42151 & 0,64 \\
\hline Others Director & 8 & 40 & 193 & 24372 & 0,36 \\
\hline$\sum$ & 20 & 100 & 527 & 66523 & 1 \\
\hline
\end{tabular}

\section{Table 2: Summary of data collected}

\section{Empirical study}

In this paper, a novel approach for competitive intelligence process is developed from conceptual and empirical study. The study aims to give more insight to mangers who wants to set up a competitive intelligence process to create knowledge necessary for making better decision. It is presented empirically how competitive intelligence is crucial for any company or organization which operates in a competitive environment.

\subsection{General Premises}

In the proposed model, information is considered the main input to the competitive intelligence process. On one hand, organizational learning is the center of this process and leads to knowledge creation. This knowledge is derived from two main sub mechanisms - strategic intent and collective representation. On the other hand, this model is oriented towards the creation of new products and services that are valuable, rare and imperfectly imitable. As a result, the following hypotheses can summarize the links that exists between competitive intelligence and knowledge management:

Hypothesis 1. Competitive intelligence is the process that allows a company to create new knowledge regarding their competitors, customers, clients, suppliers and technologies.

Hypothesis 2. Technological, competitive and environmental knowledge are created by a competitive intelligence process, as actors learn from the external and the internal environment.

Hypothesis 3. Organizational learning happens when strategic intent is renewable through a competitive intelligence process.

Hypothesis 4. Organizational learning happens, when collective representation is changed through a competitive intelligence process.

In order to test the above hypothesis, the different variables are translated into measurements. Table 3 shows the different measurements related to the variable's model.

\begin{tabular}{|c|c|c|}
\hline VARIABLE & \multicolumn{2}{|c|}{ MEASUREMENT } \\
\hline (1) Direction and Vision & \multicolumn{2}{|c|}{$\begin{array}{l}\text { What are we looking for? } \\
\text { What can we expect to happen in the future? } \\
\text { Are we sure that we have the sufficient information about our environment? }\end{array}$} \\
\hline (2) Information Gathering & \multicolumn{2}{|c|}{$\begin{array}{l}\text { Press, books, Database, Forum, Convention } \\
\text { Informal networks (Supplier, customers, competitors, subcontractor, etc.), } \\
\text { Who gathers the information? }\end{array}$} \\
\hline (3) Information Analysis & \multicolumn{2}{|c|}{$\begin{array}{l}\text { Internal and external experts } \\
\text { Meetings of analysis } \\
\text { Tools data processing (SPSS, Data mining) }\end{array}$} \\
\hline (4) Information Disseminating & \multicolumn{2}{|c|}{$\begin{array}{l}\text { Meetings } \\
\text { Reports } \\
\text { Intranet } \\
\text { E-mails } \\
\text { Phone calls }\end{array}$} \\
\hline \multicolumn{3}{|l|}{ (5) Knowledge Creation } \\
\hline & To Tacit & To Explicit \\
\hline & Socialization & Externalization \\
\hline \multirow[t]{5}{*}{ From Tacit } & Knowledge Maps & Groupware \\
\hline & Knowledge Portals & Workflow \\
\hline & & Knowledge-Based Systems \\
\hline & & Knowledge Portals \\
\hline & Internalization & Combination \\
\hline \multirow[t]{5}{*}{ From Explicit } & Innovation Support Tools & Intranet \\
\hline & & Electronic Document Management \\
\hline & & Business Intelligence \\
\hline & & Knowledge Portals \\
\hline & \multicolumn{2}{|c|}{$\begin{array}{l}\text { Errors } \\
\text { The system of roles is inefficient } \\
\text { The rules for working are not clear } \\
\text { The interface of the expertise domains is fuzzy } \\
\text { Bad use of the tools and techniques }\end{array}$} \\
\hline
\end{tabular}




\begin{tabular}{|l|l|}
\hline (6) Organizational Learning & Corrections \\
& $\begin{array}{l}\text { Change of the structure } \\
\text { Change of the culture } \\
\text { Modification to the rules } \\
\text { Improvement in the management }\end{array}$ \\
\hline (7) Collective Representation & $\begin{array}{l}\text { Change in the representations regarding external environment (threats / } \\
\text { opportunities) } \\
\text { Change in the representations regarding internal environment (strengths / } \\
\text { weaknesses). } \\
\text { Belief change }\end{array}$ \\
\hline \multirow{2}{*}{ (8) Strategic Intent } & $\begin{array}{l}\text { Renewal strategic plan } \\
\text { Renewal strategic objectives } \\
\text { Engagement of the actors }\end{array}$ \\
\hline
\end{tabular}

Table 3: Measurement

\subsection{Analyzing data}

The number of data analysis tools in management is numerous. In our study, speech analysis was done. Analysis of speech requires that certain questions should be asked with regard to the research question. To obtain answers to questions, speech must then be translated as far as possible into a measurable quantity. Table 2 presents the most common occurrences detected by Tropes Software in 20 speeches. Based on statistics generated by the Tropes Software, a contingency table was built. It is composed of 20 rows that represent the company and five columns that represent a variable. This table was used for quantitative analysis. In doing so, two techniques were used: The spearman rank correlation and factorial correspondence analysis.

\begin{tabular}{|c|c|c|c|c|c|c|}
\hline & CI & KC & OL & SI & REP & $\Sigma$ \\
\hline C1 & 21 & 15 & 18 & 15 & 11 & 80 \\
\hline $\mathrm{C2}$ & 4 & 10 & 13 & 19 & 7 & 53 \\
\hline $\mathrm{C3}$ & 5 & 13 & 41 & 21 & 16 & 96 \\
\hline $\mathrm{C4}$ & 19 & 9 & 18 & 29 & 11 & 86 \\
\hline C5 & 23 & 20 & 4 & 20 & 10 & 77 \\
\hline C6 & 12 & 26 & 30 & 20 & 14 & 102 \\
\hline C7 & 12 & 20 & 9 & 14 & 9 & 64 \\
\hline C8 & 32 & 39 & 19 & 26 & 16 & 132 \\
\hline C9 & 20 & 19 & 12 & 18 & 8 & 77 \\
\hline $\mathrm{C10}$ & 26 & 53 & 10 & 24 & 22 & 135 \\
\hline C11 & 11 & 47 & 16 & 47 & 19 & 140 \\
\hline C12 & 8 & 35 & 5 & 14 & 17 & 79 \\
\hline $\mathrm{C} 13$ & 12 & 27 & 9 & 12 & 8 & 68 \\
\hline C14 & 9 & 20 & 16 & 8 & 15 & 68 \\
\hline C15 & 50 & 43 & 16 & 33 & 18 & 160 \\
\hline C16 & 26 & 36 & 26 & 17 & 14 & 119 \\
\hline C17 & 27 & 45 & 17 & 6 & 16 & 111 \\
\hline C18 & 10 & 29 & 13 & 21 & 23 & 96 \\
\hline C19 & 7 & 18 & 7 & 12 & 3 & 47 \\
\hline $\mathrm{C} 20$ & 14 & 21 & 20 & 23 & 11 & 89 \\
\hline TOTAL & 348 & 545 & 319 & 399 & 268 & 1879 \\
\hline
\end{tabular}

Table 4: Contingency table speech / variable (20 SPEECH)

\section{Legend:}

$\mathrm{CI}=$ Competitive intelligence

$\mathrm{KC}=$ Knowledge Creation

OL $=$ Organizational Learning

$\mathrm{SI}=$ Strategic Intent

REP $=$ Representation

$\mathrm{C}$ Number $=$ Company Number

The Spearman Rank Correlation Coefficient was used to discover the strength of a link between two variables. The research looks at the strength of the link between CI and $\mathrm{KC}, \mathrm{OL}$ and $\mathrm{KC}$, SI and OL, REP and OL. When written in mathematical notation the Spearman Rank formula looks like this, where:

$$
\left(R^{2}\right)=1-\frac{6 \sum d^{2}}{n^{3}-n}
$$

$d=$ the difference between the ranks of corresponding values of $\mathrm{X}$ and $\mathrm{Y}$ $n=$ the number of pairs of values.

The use of a non-parametric test was justified by the small size of the sample ( 20 speeches). The test was carried out by using StatView. Spearman's rank correlation provides a distribution free test of independence between two variables. To do this, 
Spearman Rank Correlation provides two parameters :

$\mathrm{r}=$ Spearman's rank correlation coefficient. $p=$ thresholds of significance $(<10 \%)$.

Table 5 show a strong relationship between CI and $\mathrm{KC}$. By this result, the first hypothesis is confirmed.

\begin{tabular}{|c|c|c|c|c|}
\hline & CI-KC & OL-KC & SI-OL & REP-OL \\
\hline $\mathbf{R}$ & 0,493 & $-0,024$ & 0,325 & 0,246 \\
\hline $\mathbf{P}$ & 0,031 & 0,915 & 0,156 & 0,283 \\
\hline Result & Correlated & Not correlated & Not correlated & Not correlated \\
\hline
\end{tabular}

Table 5: Spearman's rank correlation coefficient (WHOLE SAMPLE)

\subsection{Empirical Results}

The result of the study showed a significant relationship between $\mathrm{CI}$ and $\mathrm{KC}$. However, other relationships had no claim. The full analysis cannot focus only on Spearman's rank correlation. Other authors have identified several limitations to this method, especially when the sample size is small $(<30)$. To complete the test, our study used factorial correspondence analysis to measure a manager's perception to different variables in the theoretical model. As mentioned, the contingency table drawn from lexical statistics and generated by Tropes was used for the analysis. SPSS gave us the following result:

\begin{tabular}{|r|r|r|}
\hline COMPANY NUMBER & FACTOR 1 & FACTOR 2 \\
\hline C1 & - &, 560 \\
\hline C2 &, 132 & - \\
\hline C3 & - & - \\
\hline C4 & - &, 198 \\
\hline C6 &, 330 &, 880 \\
\hline C7 &, 441 & - \\
\hline C8 &, 935 &, 341 \\
\hline C1 &, 731 &, 678 \\
\hline C10 &, 401 &, 802 \\
\hline C12 &, 902 &, 331 \\
\hline C13 &, 729 & - \\
\hline C14 &, 917 & - \\
\hline C15 &, 979 & \\
\hline C16 &, 615 & \\
\hline C17 &, 363 & \\
\hline C18 &, 683 & \\
\hline C19 &, 715 & \\
\hline C21 &, 756 & \\
\hline
\end{tabular}

Table 6: Correspondence analysis for factorial analysis

\section{Note:}

High correlation $(>, 50)$

Medium correlation (between ,25 et ,50)

Low correlation $(<, 25)$.

Observe that factorial analysis of correspondences can only be based on the 19th speech. It says that the competitive intelligence director strongly contributed to the explanation of the factorial axis 2 $(>50)$. SMEs did not participate in the factorial axis 2. A functional distinction was identified between SMEs and larger companies regarding the relationship between CI-KC, OL-KC, SI-LO, REPOL. Three homogeneous block profile speeches could be identified, that contribute to the construction of the factor 1: $(\mathrm{C} 7, \mathrm{C} 10, \mathrm{C} 12, \mathrm{C} 13$, C19), (C8, C11, C18), (C14, C16). Two blocks of speech profiles involved in the formation of the factor 2 were detected: (C5, C9), (C1, C8).

This classification is significant because it contributes to finding the speeches that give more information regarding the variable model. For example, G1 explains the $\mathrm{KC}$, while as $\mathrm{G} 2$ is interested in CI and the REP, and G3 gives more information about IS.

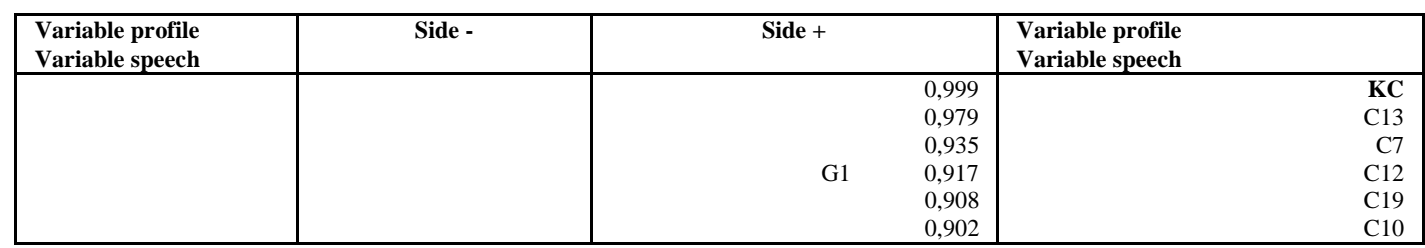




\begin{tabular}{|c|c|c|c|c|}
\hline & & $\mathrm{G}^{2}$ & $\begin{array}{r}0,756 \\
0,731 \\
0,729 \\
0,715 \\
0,705 \\
0,683 \\
0,615 \\
0,520 \\
\end{array}$ & $\begin{array}{l}\text { C18 } \\
\text { C8 } \\
\text { C11 } \\
\text { C17 } \\
\text { REP } \\
\text { C16 } \\
\text { C14 } \\
\text { CI }\end{array}$ \\
\hline $\begin{array}{l}\text { C1 } \\
\text { C3 } \\
\text { OL }\end{array}$ & $\begin{array}{l}-0,386 \\
\\
\\
-0,191 \\
-0,181 \\
-2,39^{\mathrm{E}}-02\end{array}$ & $\mathrm{G}$ & $\begin{array}{r}0,472 \\
0,441 \\
0,401 \\
0,363 \\
0,379 \\
0,330 \\
0,132\end{array}$ & $\begin{array}{l}\text { C20 } \\
\text { C6 } \\
\text { C9 } \\
\text { C15 } \\
\text { SI } \\
\text { C5 } \\
\text { C2 }\end{array}$ \\
\hline
\end{tabular}

Table 7: Variable profile and Variable Speech

Note:

$G=$ Group of companies with similar perception

\section{Conclusions}

The model is based on a competitive intelligence process and the theory of action developed by Argyris and Schôn (1978). According to Havenga and Botha (2003) the entire process should be guided by the company's strategy. The company's strategic intent, mission and strategic objectives should act as a constant guide for the competitive intelligence process. This paper describes a novel approach for competitive intelligence. It explains in theory how competitive intelligence can add value to companies by creating new knowledge. The views of several writers are assembled to describe the process, although they have different emphases. Fuld (2000) believes that competitive intelligence should build on and around the culture of the organisation. Our research claims that competitive intelligence allows companies to create new knowledge, if they can learn to align their competitive intelligence process with strategic intent and with collective representation. It means that companies should know how to use their competitive intelligence strategically to find new opportunities and minimize risks.

\section{Acknowledgements}

The author feels a debt of gratitude to all directors for their openness, helpfulness and their insightful comments regarding this work. May their spirit continue to enlighten their lives and those of others.

\section{References}

Achard, P, Bernat, J.-P. 1998. L'intelligence économique: Mode d'Emploi. ADBS Editions.

Argyris, C, Schôn, D. 1978. Organizational learning: a theory of action perspective. Adison Wesley.

Barney, J, 1991. Firm resources and sustained competitive advantage, Journal of Management, $\mathrm{n}^{\circ} 17$.
Barney, J.B, Wright, M, Ketchen, D.J. 2001. The resource-based view of the firm: Ten years after 1991. Journal of Management 27 (6).

Calof, J. 2001. Competitive intelligence and the small firm-Requirements and barriers. Available online at URL: http://www.sbaer.edu/Research/2001/ICSB/A6-2.HTM.

Campbell, A, Yeung, S. 1991a. Creating a sense of mission, Long Range Planning, Vol $24, \mathrm{n}^{\circ} 2$.

Charue, F. 1992. Les entreprises peuvent elles apprendre, Cahiers $d u C R G, \mathrm{n}^{\circ} 9$, Paris.

Cohen, W. Levinthal, D. 1994. Fortune favors the prepared firm, Management Science, Vol 40, $\mathrm{n}^{\circ} 2$.

Crane, A. 2005. In the company of spies: when competitive intelligence gathering becomes industrial espionage, Business Horizons, Vol 48 (3).

du Toit, A.S.A. 2003. Competitive intelligence in the knowledge economy: what is in it for South African manufacturing enterprises? International Journal of Information Management, Volume 23, Issue 2, April.

Eisenhardt, K. M. 1989. Building theories from case study research, Academy of Management Review, vol 14, $\mathrm{n}^{\circ} 4$.

Fuld, L. 2000. Intelligence software: reality or still virtual reality? Fuld et co, Cambridge, Massachusetts. Available online at URL: http://www.fuld.com

Hamel, G. 1996. Strategy as revolution, Harvard Business Review, Vol 74.

Hamel, G. Prahalad, C.K. 1989. Strategic intent, Harvard Business Review, ${ }^{\circ} 3$.

Hannan, M.T, Freeman, J. 1989. Organizational ecology. Harvard University Press

Havenga, J. Botha, D. 2003. Developing competitive intelligence in the knowledge based organization. Available online at URL: http://www.saoug.org.za/archive/2003/0312a.pd f 
Huber, G.P. 1991. Organizational learning: the contributing processes and the literature, Organization Science, 2, 1.

Ingham, M. 1994. L'apprentissage organisationnel dans les coopérations, Revue française de gestion, $\mathrm{n}^{\circ} 97$, janvier-février.

Levet, J. L. 2001. Intelligence économique: mode de pensée, mode d'action, Economica, Paris.

Lipton, M. 1996. Demystifying the development of an organizational vision, Sloan Management Review, Summer.

Nonaka, I. 1994. A dynamic theory of organizational knowledge creation, Organization Science, Vol 5.

Nonaka, I, Konno, N. 1998. "The Concept of 'Ba': Building a Foundation for Knowledge Creation." California Management Review 40(3).

Nonaka, I, Takeuchi, H. 1994. The knowledge creating company. Oxford University Press.

Nonaka, I, Takeuchi, H. 1995. The knowledge creating company. How Japanese companies create the dynamics of innovation. NY: Oxford University Press.

Nonaka, I, Takeuchi, H. (Eds). 1997. La connaissance créatrice. La dynamique de l'entreprise apprenante. De Boeck Université, Bruxelles.

Oubrich, M. 2005. La création des connaissances dans un processus d'intelligence économique, PhD dissertation, Aix Marseille University, France.

Polanyi, M. 1966. The tacit dimension. Garden City, NY: Doubleday

Porter, M.E. 1990. The competitive advantage of nations. New York, The Free Press.

Prescott, J.E. 1999. The Evolution of Competitive Intelligence: Designing a process for action, APMP Spring. Available online at URL: http://www.apmp.org/fv-154.aspx

Rouach, D, Santi, P. 2001. Competitive Intelligence Adds Value: Five Intelligence Attitudes, European Management Journal Vol. 19, No. 5, October.

Rittenburg, et al. 2006. An ethical decision-making framework for competitor intelligence gathering, Journal of Business Ethics, Vol 70. Available online at URL: http://www.springerlink.com/content/e3582656 $\underline{18678457 /}$ 